\title{
Performing Anatomy
}

\author{
RONALD HUEBERT \\ Dalhousie University and the University of King's College
}

Peut-on dire qu'il y avait quelque chose de véritablement théâtral dans les événements ayant eu lieu dans les soi-disant théâtres de lanatomie de la Renaissance? À cette question, je propose quatre réponses, différentes mais liées, basées sur les archives étudiées par de précédents spécialistes et sur les preuves visuelles nous permettant d'imaginer la manière dont les dissections s'effectuaient il y a 400 ans. La leçon d'anatomie du docteur Nicolaes Tulp (1632) de Rembrandt représente une pièce cruciale du puzzle. Ce tableau dramatise le conflit entre le côté manuel de lanatomie et la dépendance de cette discipline sur des autorités écrites. J'infère, à partir des témoins disponibles, que les dissections anatomiques constituaient un événement théâtral, qu'elles attiraient des spectateurs, qu'elles créaient un environnement dans lequel un artiste virtuose pouvait sépanouir, et qu'elles représentaient des conflits culturels divers. Ce qui a eu lieu dans les théâtres d'anatomie était un type de performance facilement compatible avec les descriptions de théâtre de Richard Southern, par exemple, dans The Seven Ages of the Theatre.

$\mathrm{W}$

as there anything genuinely theatrical about the events carried out in the so-called Anatomy Theatres of the Renaissance? ${ }^{1}$ From time to time this question has attracted the notice of writers on iconography, ${ }^{2}$ cultural history, ${ }^{3}$ and English drama, ${ }^{4}$ typically as a supplement to some other item which sets and dominates the particular scholar's agenda. On this occasion I propose to make it the centre of attention. In due course I will be offering four different but related answers to the question I have posed. My argument will depend to some considerable degree on the archival material studied by the scholars already alluded to, and by recent historians of the anatomical project. ${ }^{5}$ But it will depend even more heavily on several important strands of visual evidence which enable us to imagine how a dissection might have been performed 400 years ago. 
Before turning to the visual evidence, it may be of interest and value to pose a theoretical question that logically precedes this enquiry, namely, what is it that prompts us to describe an event as "theatrical" in the first place? This is an unanswerable question, in the sense that it will elicit a different response from each theoretically motivated participant in the theatrical experience, whether that participant is an actor, a playwright, a director, or a member of the audience: Stanislavski, Shakespeare, Artaud, and Jacques Rancière would (and did) give widely divergent answers. ${ }^{6}$ Rather than survey the full range of possibilities at this point (an enterprise that would be doomed to failure in any case), I propose to select the position outlined by Richard Southern, a writer on theatre whose work I have long admired, and whose intellectual range is copious enough to allow for the discovery of theatrical elements in unexpected settings.

In Southern's most widely read book, The Seven Ages of the Theatre, he devotes six tightly packed preliminary pages to defining what he takes to be "The Essence of Theatre." When you strip away all of the items that have come to be identified with the theatre because of historical circumstances but are not essential to the experience - such items as scenery, artificial lighting, elevated stages, and so forth - you are left at last with an irreducible theatrical paradigm: "the act, that is to say, of performing something before a group of other people." this deliberately spare definition Southern is willing to add qualifications that inflect but do not fundamentally alter the paradigm. I take these qualifications to be three in number, and for convenience I will name and describe them as follows: (1) manner over matter, (2) face to face, and (3) theatrical thrill.

Having drawn a distinction between those arts (the creative arts) in which something is made, and those (the performing arts) in which something is done, Southern goes on to argue that, for the performing artist, how matters more than what; when you perform a trumpet concerto your audience will be keenly interested in how you play it, even if they already know exactly what it is that the composer has asked you to do. So too for the theatrical performer, who knows that "the secret of the theatre does not lie in the thing done but rather

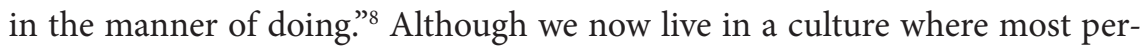
formances are mediated to us digitally or in other electronic ways, for much of theatrical history, and certainly during the sixteenth and seventeenth centuries, theatrical performance required the performers and spectators to meet at a set time in a particular place. This too is a requirement of theatre as a performed art which "depends on a concentrated effort on one particular occasion," an 
occasion which brings performers and spectators into direct contact with one another. Southern's word for the third qualification is "nervousness," ${ }^{10}$ a word he uses to identify the feeling of heightened awareness which the performer needs to develop if he is to control and direct the energies of the spectators who, by virtue of their sheer numbers and their "mass strength," ${ }^{11}$ could wreck the performance and ruin the reputation of the performer if they chose to do so. I find Southern's description of this frisson utterly convincing, but I have chosen to rename it the theatrical thrill that can be felt by performers and spectators alike. The theoretical position I have outlined here implies that a dramatic script, an arrangement of scenery, the wearing of masks or costumes, or for that matter musical accompaniment are not essential elements of theatrical experience, however highly valued they may have been in certain theatrical venues and certain historical periods. I will now set the Southern model to one side, while I describe and analyze some of the visual evidence that has a bearing on the question with which I began. At the end of this essay, the model will no doubt be of some further use.

The first image I appeal to is a photograph of the interior of the Teatro Anatomico built in the Palazzo dell'Archiginnasio, Bologna, in 1637, renovated in the eighteenth century, damaged by bombing in World War II, and painstakingly restored to its original splendour subsequently (figure 1). I begin here because it's the one anatomy theatre of which I have first-hand experience. ${ }^{12}$ In discussing it, however, I will rely not so much on casual impressions as on the dedicated scholarship of Giovanna Ferrari, who describes this space as follows:

The dissecting table was surrounded by a balustrade to protect it from the scholars who crowded round it. Three rows of benches and an aisle ran around all four walls. The anatomy professor's cathedra was situated along one of the end walls, as were the prior's chair and the seats for the counselors. Against the opposite wall sat the authorities. Along the side walls, "on the right will sit the university, accompanied by its porters with the maces, and the notary; on the left, on the other hand, will sit the entire body of doctors, according to the seniority of their doctorates; and all around, the young scholars".

Any seats left over were occupied by ordinary citizens, for whom there was also standing room. ${ }^{13}$ 


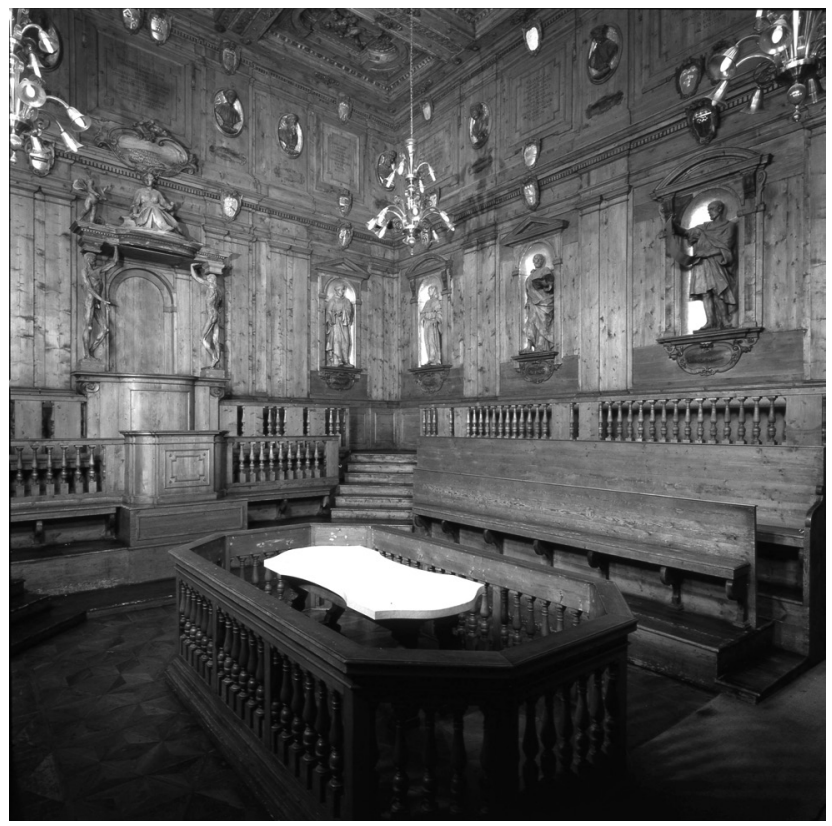

Figure 1: Teatro Anatomico, Bologna (1637), Courtesy of Biblioteca Comunale dell'Archiginnasio, Bologna.

As even this brief account implies, what was happening at a public dissection in the Teatro Anatomico could not simply be described as teaching anatomy to the medical students of the University of Bologna. Just how much would be left out by such a designation can be pointed out by sketching in some of the circumstances and conventions connected with public dissections in Bologna.

Consider, for example, the size and composition of the audience, which could be as large as "several hundred" ${ }^{14}$ persons, and which included authorities from the highest civic and university levels, as well as ordinary people with no special authority or training. Members of the general public would be expected to pay for admission. The time of year for public dissections was strictly regulated. In Bologna these events were limited to the period of carnival: roughly the second half of January. Different local jurisdictions specified different dates, but all regulations identified some of the coldest days of the year. The need for this regulation will be obvious to anyone who considers the rate at which a cadaver is likely to decompose in an era without refrigeration. The structure 
of the Teatro Anatomico featured not one, but two centres of interest: the marble slab on which the cadaver was placed, and the cathedra from which the professor of anatomy could observe and speak. The actual dissection would be carried out by the professor's assistants, following his instructions. But the most important discursive event came in the form of a dispute. Representatives of the scholars, and any of the learned doctors in attendance, could ask questions of the professor. He was obliged to reply. So, being the senior Professor of Anatomy at the University of Bologna became a high-stakes game of wit, in which reputations could be quickly made or unmade. Ferrari claims that the public dissection was "above all" a "ceremony" in which various kinds of symbolic power were exhibited and negotiated. It frequently attracted the notice of foreign visitors to Bologna and, especially because of its strong association with carnival, it became an event that promised to "restore the university's prestige and the financial health of the city." ${ }^{\prime 5}$

The next major visual exhibit will be Rembrandt's Anatomy Lesson of Dr. Nicolaes Tulp, but before turning to this acknowledged masterpiece I recommend stopping briefly in Leiden, the city of Rembrandt's birth, education, and early development as a painter. The University of Leiden had built its own Anatomical Theatre in 1597 and, to judge by all of the available evidence, including the engraving by Willem Swanenburgh made in 1610 and reproduced here in an imprint dated 1644 (figure 2), it was radically unlike the structure that would soon be built at the University of Bologna. Indeed, the Leiden theatre seems to have been modeled on the Teatro Anatomico of the University of Padua (1594). Like its Padovan model, the Leiden Anatomical Theatre had an oval shape with six tiers of galleries appropriately raked so that no spectator's vision of the central event would be obstructed. Jonathan Sawday describes this theatre as "an architectural lesson in human mortality." ${ }^{16}$ This interpretation seems almost inescapable, once the profusion of skeletons - human, animal, and even avian - has been observed. William S. Heckscher deserves credit for what has become the prevailing interpretation of this structure as a memento mori, and for highlighting the way in which the drawing alludes to the belief that death is the result of the fall of humankind. "Prominently we see Adam and Eve, two animated skeletons, flanking the Tree of Knowledge in the center foreground." ${ }^{17}$ Notice that skeletal Eve holds the forbidden fruit in the palm of her right hand, that skeletal Adam extends his right hand as if preparing to receive it, and that the Serpent wreathes himself in coils around the trunk of the fatal tree. 


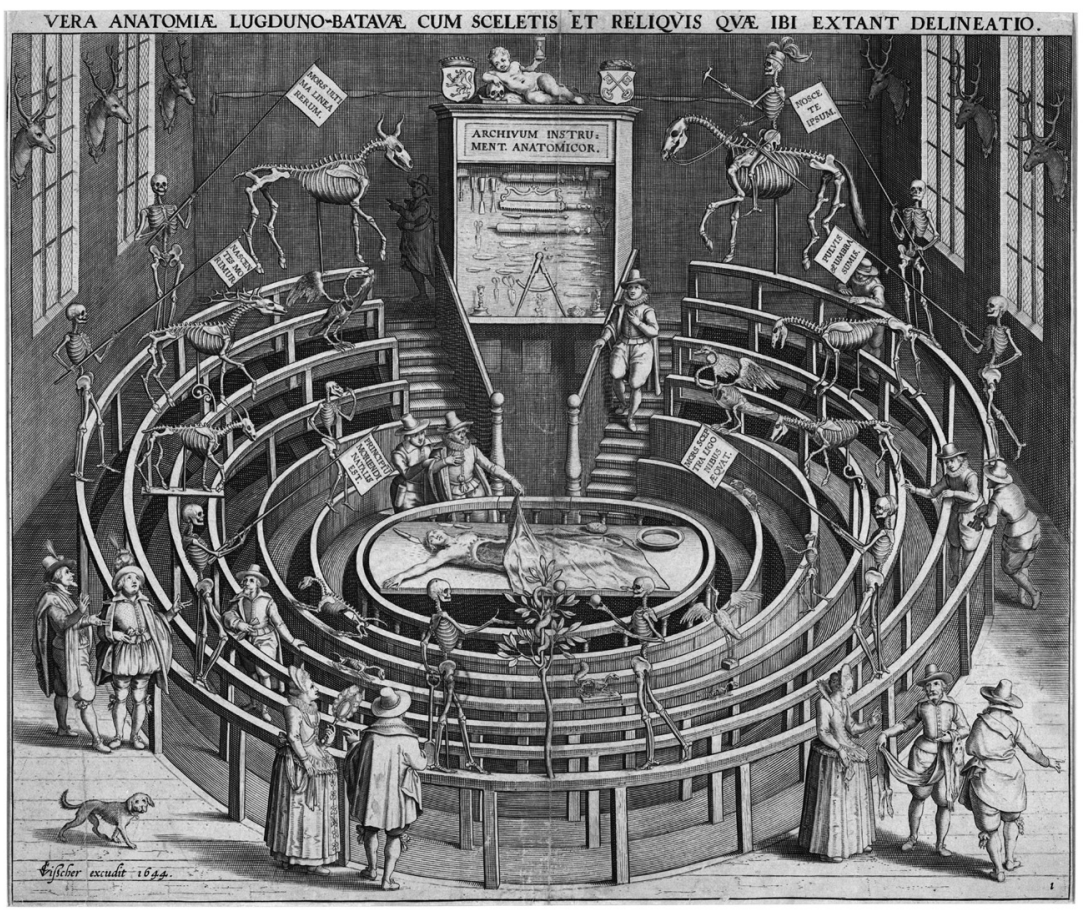

Figure 2: Willem Swanenburgh, Engraving of the Anatomical Theatre, Leiden (1644 imprint), Courtesy of Leiden University Libraries, P 315-III N19.

Although the dissecting table is laden with a disemboweled and partly shrouded human corpse, the Leiden Anatomical Theatre is pictured here as we might imagine it on those many days of the year when no anatomy lesson is being performed. On these ordinary days of the year there are still spectators who visit it as if it were a museum or a cabinet of wonders. There is still a scene and a spectacle for them to observe, but it is the story of our mortality that is being enacted.

In a second and less distinguished engraving of the Leiden Anatomical Theatre, this one by F. de Wit, ${ }^{18}$ the galleries are filled with spectators of both sexes who ignore the presence of the skeletons while they watch a dissection unfold. The anatomist on this occasion is Dr. Peter Paaw, Professor of Medicine at Leiden and mentor to Nicolaes Tulp, who studied in Leiden before moving to Amsterdam, where he would become at length the star subject of Rembrandt's painting. The skeletons of Adam and Eve have been moved slightly to the left 
and the right, and the tree between them has been decisively moved to a position behind Eve, so as not to obstruct our view of the female corpse whose vital organs Dr. Paaw has already exposed. But perhaps these are revisions introduced by the draughtsman (J. C. Woudanus) or the engraver, and had no bearing on the scene as it unfolded in the crowded theatre. Of one thing we can be certain, however: this is a hands-on anatomical demonstration, in which Dr. Paaw himself stands right next to the slab on which the cadaver lies; he appears to be holding a vital organ in his left hand, while he makes a rhetorical gesture with his right in the general direction of a book which lies open before him. This arrangement invites further commentary, but I will suspend it here in order to take the next step in this brief survey of visual texts.

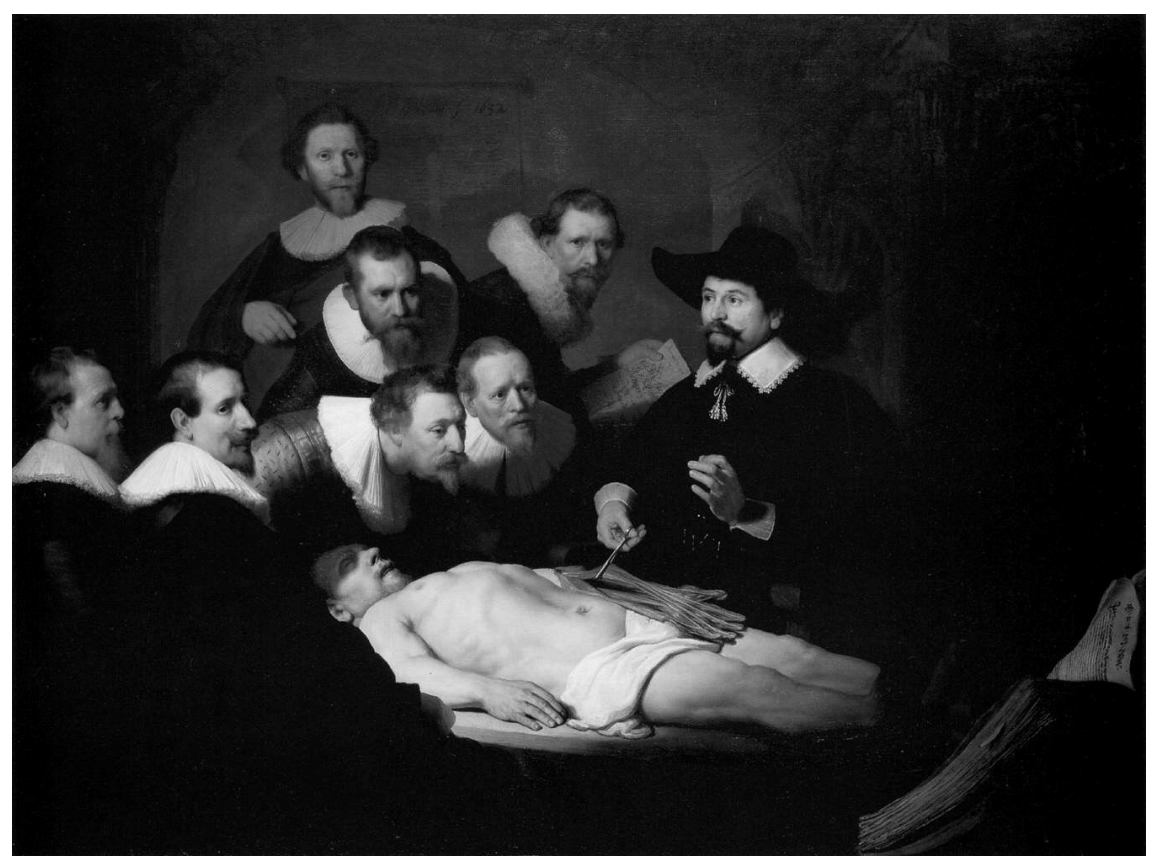

Figure 3: Rembrandt van Rijn (1606-1669), The Anatomy Lesson of Dr. Nicolaes Tulp (1632, canvas 169.5 x $216.5 \mathrm{~cm}$ ), The Hague, Royal Picture Gallery Mauritshuis.

Rembrandt's Anatomy Lesson of Dr. Nicolaes Tulp (figure 3) is a celebrated work that will doubtless be familiar to most readers already: it has been an object 
of study for historians of art, for historians of medicine, for historians of culture, and even for critical theorists. ${ }^{19}$ Heckscher observes that "the first impression that both fascinates and puzzles the modern beholder of Rembrandt's painting is the role played by the human eye." ${ }^{20}$ This is a brilliant opening gambit that can, I think, be pressed into further service as a first step in the direction of acknowledging that the whole painting is a comprehensive representation of what we might call the game of spectatorship. The second step would be to notice how deliberately Rembrandt insists that the various spectators, all of them members of the Guild of Surgeon-Anatomists of Amsterdam, are decidedly not looking at the same thing. This general impression takes on the force of conviction if we look more closely at the group of five figures directly above the cadaver (figure 4).

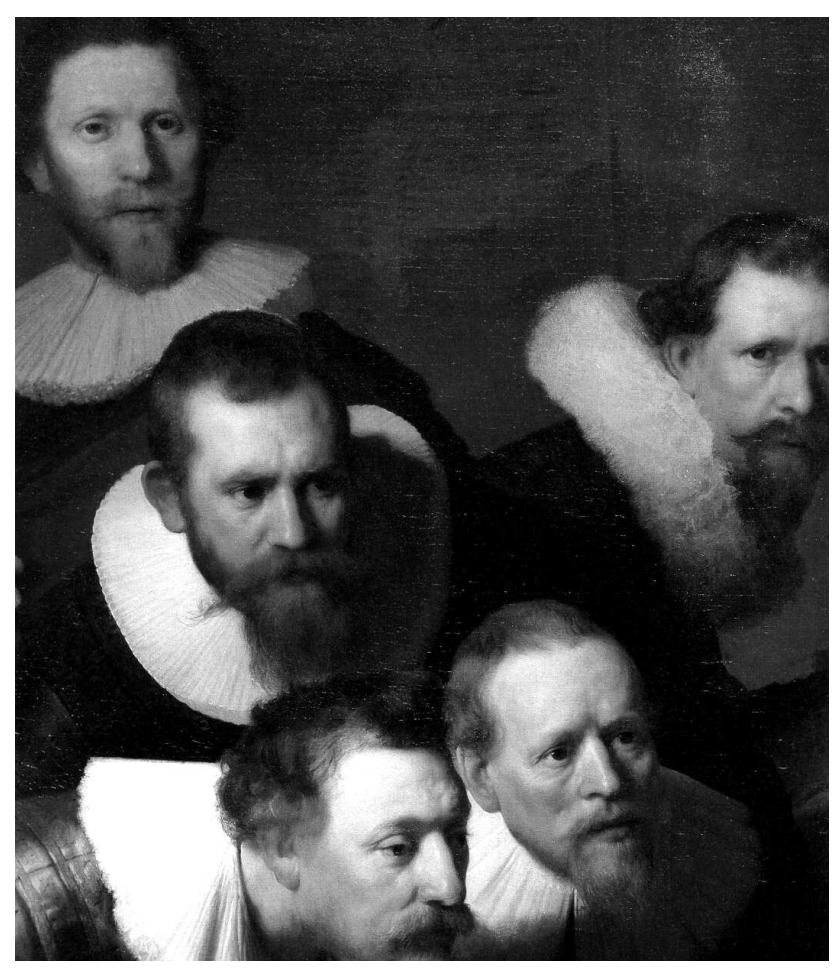

Figure 4: Rembrandt van Rijn (1606-1669), The Anatomy Lesson of Dr. Nicolaes Tulp, detail (1632, canvas 169.5 x $216.5 \mathrm{~cm}$ ), The Hague, Royal Picture Gallery Mauritshuis. 
Let us ignore the topmost figure, Fran[s] van Loenen according to Heckscher's painstaking analysis; he seems to be staring rather vacantly at us, and we will not be surprised or disappointed to discover that his presence in the painting was a later addition, doubtless by someone other than Rembrandt. ${ }^{21}$ If we now turn our attention to the faces of the two men closest to the cadaver, it will strike us at once that they too are gazing at different objects. The man on our left, Jacob de Witt, casts his gaze downward at an angle of perhaps 30 degrees below horizontal; the man to our right, Mathys Kalkoen, is looking downward as well, but not nearly so sharply, and he seems moreover to be looking at an object some distance away. If we now put these men back into the big picture it becomes clear that de Witt's gaze is focused right on the cadaver's left arm, doubtless at the very point where Dr. Tulp is picking up the muscles and tendons with his surgical tongs; Kalkoen is looking past the cadaver and the anatomist in the effort to read from a book (in large folio format) which stands propped open in the bottom right-hand corner of the painting. The book does not need to be identified for us to draw the inference that it is the anatomy textbook considered authoritative by the Guild.

Once the dichotomy between anatomy as a hands-on experience and anatomy as a discipline with written authorities has been established, the demeanour of the other Guild members becomes explicable. Jacob Blok, whose face appears directly above de Witt's, seems also to be looking downward, probably at the cadaver's arm and hand. Adriaan Slabraen, to our left of de Witt, seems to have the nearly horizontal gaze which would make the open book its target. If I am right about this, then so far we have two men looking at the cadaver, two at the book. The man whose head is closest to Dr. Tulp's, and who holds a sheet of paper in his hand, is Hartman Hartman. His gaze, like Fran[s] van Loenen's, is directed at us, or at least it seeks its object on the viewer's side of the picture plane. His gaze may be Rembrandt's way of alluding to the inescapable fact that we too are participants in the game of spectatorship. Hartman's gaze, unlike van Loenen's, is not empty; it seems rather to be filled with a degree of anxiety, as if the artist were expressing through him anxiety about the reception of his own performance. The one remaining viewer, Jacob Koolvelt, situated nearest the left-hand margin of the painting, may also have been a later addition. Whether or not this is so, Koolvelt appears to be the only spectator who is looking directly at Dr. Tulp: not at his anatomical performance, but at his handsome, actorly face. 
And this brings us to the gaze of Dr. Tulp himself. He is looking neither at the cadaver nor at any of the men gathered here, but appears to be playing to a much larger audience than the one we see pictured. Furthermore, his gaze is directed upwards, toward 'the gods' as the theatrical cliché has it. The exact dimensions and circumstances of the Amsterdam Anatomy Theatre have not been documented, and Rembrandt's painting, with its characteristically dark background, gives us no assistance in this matter. But if we imagine a scenario similar to the one in Leiden, with six concentric galleries raked upwards, then Dr. Tulp's gaze becomes an appropriate and meaningful part of his performance. His show is closely observed by an inner circle, whose names are recorded, by the way, on the sheet of paper held by Hartman Hartman. But if this inner circle is of special significance here, perhaps as patrons who brought the idea of this group portrait into existence, the performance of the anatomist is intended for a much wider audience.

Before leaving this painting I would like to observe that hands are important too, both the wonderfully expressive hands of Dr. Tulp, and those of the recently executed criminal, Adriaan Adriaanz, also known as Aris Kindt. Dr. Tulp uses his right hand to control his surgical instrument, and his left to communicate, rhetorically, to his audience. At the same time he is drawing attention to the left arm and hand of the man whose body has been expropriated in order to make the performance possible. Compared to the right arm of Aris Kindt, which lies at his side in what looks like a natural pose, this left arm and hand have taken on a surrealistic life of their own; death and dismemberment has made of them the designated objects of the gaze.

A brief diversion to England may be in order at this point, not only because the English staged anatomical performances of their own, but also because London had developed a theatrical culture that was the envy of Europe. This is perhaps a large claim to advance, but it is easy to support it. The evidence would include such documents as the Dutchman Johannes de Witt's famous drawing of the Swan Theatre (c. 1596), preserved in a copy made by another Dutchman (Arend van Buchell), and reproduced in any number of printed or electronic studies of Elizabethan stages. ${ }^{22}$ But it would include more recondite materials too, such as the accounts of theatrical events in London which the Venetian ambassador sent back to his employers. ${ }^{23}$ The point I wish to make here is a rather more specific one, however, and it is this: in London, where dissections were carried out by the Barber Surgeons 
Guild, a theatre for the purpose of staging these events was designed in 1636 by the leading theatrical architect and scenographer of the day, Inigo Jones. Christian Billing has studied Jones's designs, and other supplementary material, and has created a digital reconstruction of the Barber Surgeons' Anatomy Theatre, as it would have looked in $1636 .{ }^{24}$ The result is a pattern of concentric oval galleries enclosing a dissection table, again on the model of the famous and frequently reproduced Teatro Anatomico at the University of Padua, constructed in $1594 .{ }^{25}$ Perhaps it would be worthwhile to recall, at this point, that the numerous foreign scholars who attended dissections at the University of Padua included the Englishmen William Harvey (1578-1657) and Sir Thomas Browne (1607-82).

The final phase of my argument takes me to Padua at last where, long before the Teatro Anatomico was built, Andreas Vesalius made a name for himself as the anatomist everyone would have to reckon with. I begin with the title page to Vesalius's De humani corporis fabrica (figure 5).

There is a rich archive of commentary about this title page, much of it devoted to interpreting the iconography of even the smallest details. ${ }^{26} \mathrm{I}$ will make only two points, both of which I owe to Jonathan Sawday's brilliant interpretation of this visual text. First, this is not the recreation of a particular anatomy theatre or of a particular event. Rather, and my second point comes in the form of a quotation from Sawday, "What is depicted is no less than a demonstration of the structural coherence of the universe itself, whose central component the principle of life concealed within the womb - Vesalius is about to open to our gaze. ${ }^{27}$ The image we have before us is of the anatomist opening the female body to observation, and this is the motivation for the implicit claim to secrecy. There is also a less subtle claim for our attention here. All of the evidence would suggest that members of the public would pay higher prices to see a dissection if the body were female. ${ }^{28}$ This result may have been caused by the law of supply and demand: there were, after all, many more executions of male criminals in Early Modern Europe than of females. But there must also have been a mystique about the reproductive capacities of the female body that elicited both curiosity and payment. 


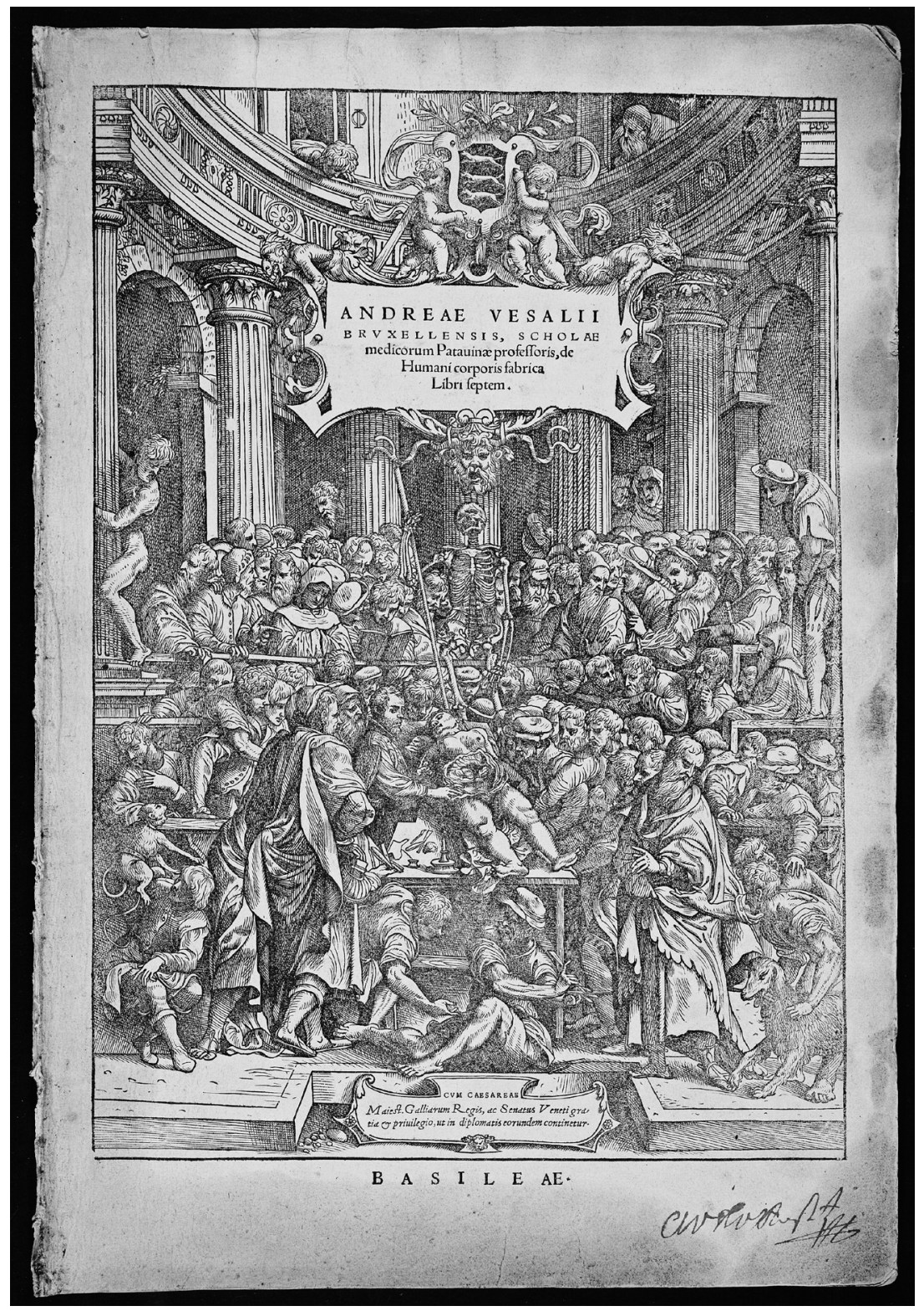

Figure 5: Andreas Vesalius, De humani corporis fabrica (Basel: J. Oporinus, 1543), title page. This item is reproduced by permission of The Huntington Library, San Marino, California. 


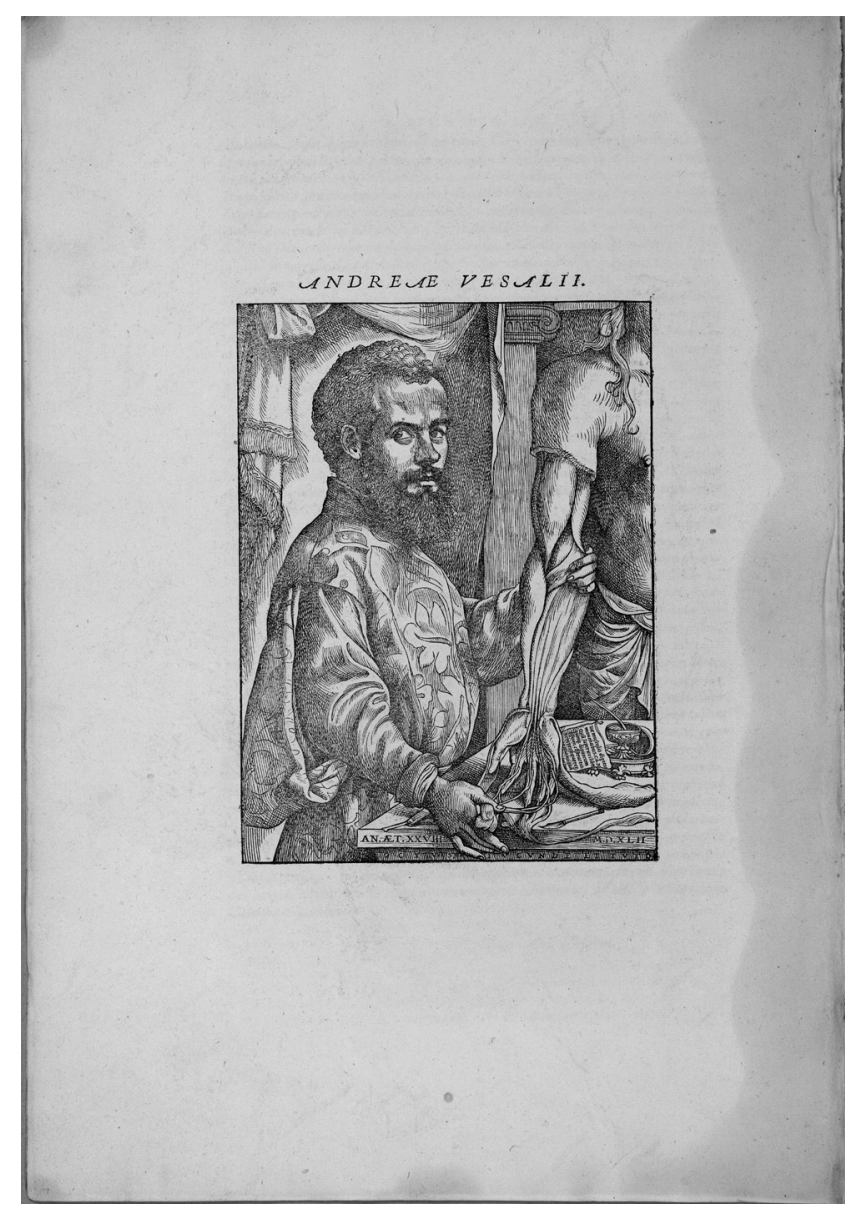

Figure 6: Joannes Stephan Van Calcar, "Andreas Vesalius as Anatomist of Arm and Hand," in Vesalius, De humani corporis fabrica (Basel: J. Oporinus, 1543). This item is reproduced by permission of The Huntington Library, San Marino, California.

The final image to which I will refer is a woodcut by Joannes Stephan Van Calcar, "Andreas Vesalius as Anatomist of Arm and Hand," as printed in De humani corporis fabrica (figure 6). Here we are in the presence of the virtuoso performer. As Hecksher points out, "Vesalius was proudly conscious of having paved the way for his revolution in anatomy when, as an undergraduate, he 
performed a feat hitherto unattempted: the dissection of the muscles of the human hand." ${ }^{29}$ Vesalius of course had far more than a precocious beginning to his credit. He was arguing at every turn that observed evidence should win over textual authority, even if that authority was as firmly established as Galen's. And for this reason the position of the anatomist in Vesalius's practice is a sharp break with tradition. Instead of pronouncing ex cathedra, the anatomist is there with the cadaver, opening it, touching it, moving it and making it meaningful in new ways. This is a legacy that Vesalius will pass on to those who admire and emulate him, including Dr. Paaw of Leiden and Dr. Tulp of Amsterdam.

Was there anything genuinely theatrical about the events carried out in the so-called Anatomy Theatres of the Renaissance? The brief and informal survey which I have conducted in response to this question may not lead to conclusions, strictly considered, but I think there are nonetheless inferences that we may draw. First of all, the practice of anatomical dissection created a theatrical scene, a theatrical setting, and a theatrical occasion. The evidence from the Teatro Anatomico, Bologna, would in itself support this inference, but I think that other jurisdictions from around Europe would lend further support. The practice of charging admission to these events would not have been possible had people not thought of them as a kind of theatrical entertainment.

Secondly, the practice of anatomy fostered a reliance on and an encouragement of spectatorship. Rembrandt's Anatomy Lesson of Dr. Nicholaes Tulp foregrounds the question of spectatorship quite beautifully, as I have tried to argue in some detail. Would we then be entitled to describe the public dissection as a voyeuristic experience? Yes, but this would be a voyeurism without consequences, at least for the already deceased cadaver, and therefore not legitimately subject to shame.

Like many other forms of theatre, anatomical dissection seems to have created a need for the virtuoso performer. Andreas Vesalius and Nicholaes Tulp are conspicuous examples of anatomists who step forward into this role. But there are many others whose names are never mentioned now, except in the research agendas of the most assiduous scholars. I am thinking here of Giulio Cesare Aranzio, anatomist and surgeon in the University of Bologna in the late sixteenth century, "an outspoken champion of his own professional worth, as well as of the importance of public anatomy." ${ }^{30}$ Yesterday's virtuoso performer may not have made any significant mark on the scientific record, so to speak, but he was still someone whom people enjoyed watching. 
Finally, the Anatomy Theatres created a venue for the enactment of certain kinds of conflict. The disputation was itself a dramatic form in which an authoritative figure would be challenged, and would either survive unimpaired (or in some cases augmented), or would suffer the decline of his reputation. This was a personal drama well worth watching for anyone connected to the social or intellectual circle in which it was being played out. There were also cultural dramas being staged here, in which far more was at stake than a single person's reputation. Sir Thomas Browne would declare, in Religio Medici, that "there are two bookes from which I collect my Divinity; besides that written one of God, another of his servant Nature, that universall and public Manuscript, that lies expans'd unto the eyes of all" (1.16). ${ }^{31}$ Browne wants to deny the conflicts that arise from consulting both books, and perhaps he should have known better. He had, after all, studied embryology at the University of Padua, where both Vesalius and Galileo had left their mark. The Anatomy Theatres were among the locations in which the great battles about what counts as knowledge were being played out. This is a kind of theatre that continues to matter in our world as surely as it did in Bologna 400 years ago.

If we return now to the synoptic account of the theatre as a phenomenon which I adapted from Richard Southern at the outset, it will be easy to demonstrate that, with one exception, the inferences I have drawn from the visual record are compatible with the theoretical model. All of the visual evidence implies that an act is being performed before a group of people. Because the act is always the same one (a dissection) and therefore in one sense predictable, how this act is performed is therefore of utmost importance. The where and when are important too, and precisely decided in advance so as to specify an occasion during which the spectators and performer(s) will meet face to face. The body language of the virtuoso performer would suggest that he knows all about the theatrical thrill that performance entails, and the rapt attention of the spectators in the Rembrandt painting would suggest that they feel a different but complementary frisson.

That leaves only the recurrent evidence of conflict unaccounted for. Southern does not use the word "conflict" in his description of the essence of theatre. Accounts of theatre that do make conflict a defining property are likely to introduce it as an aspect of the plot of what is being performed, and therefore may imply that it arises from the dramatic script. ${ }^{32}$ While the script may indeed articulate a path that conflict is going to take, I believe that conflict of 
some kind is an inherent property of theatre, whether scripted or not. Conflict has certainly been observable in every theatrical event at which I have been a spectator, insofar as I can remember; and it is visibly present even in theatrical forms which repudiate plot (such as theatre of the absurd) or don't require written scripts (such as commedia dell'arte). I should therefore want to add just this further qualification to Southern's model of the theatrical paradigm: conflict of some kind (between the gods and human beings, between young and old, between sibling rivals, between opposing interpretations of the universe) will always be part of the theatrical event. And that is why, I believe, the performances enacted in the Anatomy Theatres of the Renaissance were not only technically but also profoundly theatrical.

\section{Notes}

1. I am grateful to William W. E. Slights, whose advice I sought at a time when this project was little more than a single question, and who responded with characteristic generosity; to Boris Kablar and Hélène Cazes, who created opportunities for me to present my work orally to the Anatomy Seminar at Dalhousie University and the meetings of the Canadian Society for Renaissance Studies respectively (both in May 2009); and to Moira Donovan, on whom I relied for research and technical assistance in the final stages of preparing this article.

2. William S. Heckscher, Rembrandt's Anatomy of Dr. Nicolaas Tulp: An Iconological Study (Washington Square: New York University Press, 1958), p. 28.

3. Jonathan Sawday, The Body Emblazoned: Dissection and the Human Body in Renaissance Culture (London: Routledge, 1995), pp. 63-64.

4. Michael Neill, Issues of Death: Mortality and Identity in English Renaissance Tragedy (Oxford: Clarendon Press, 1997), pp. 117-20.

5. See, for example, Andrew Cunningham, The Anatomical Renaissance: The Resurrection of the Anatomical Projects of the Ancients (Aldershot: Ashgate, 1997); Andrea Carlino, Books of the Body: Anatomical Ritual and Renaissance Learning, trans. John Tedeschi and Anne C. Tedeschi (Chicago: University of Chicago Press, 1999); and Nanci G. Siraisi, History, Medicine, and the Traditions of Renaissance Learning (Ann Arbor: University of Michigan Press, 2008).

6. See, for example, Konstantin Stanislavski, An Actor Prepares, trans. Elizabeth Reynolds Hapgood (New York: Theatre Arts Books, [1948]), p. 60, Hamlet's advice to 
the players in Hamlet, ed. Harold Jenkins, Arden Shakespeare (London: Methuen, 1982), 3.2.20-24, Artaud, The Theater and Its Double, trans. Mary Caroline Richards (New York: Grove Press, 1958), p. 24, and Jacques Rancière, The Emancipated Spectator, trans Gregory Elliott (London: Verso, 2009), pp. 6-8.

7. The Seven Ages of the Theatre (London: Faber, 1962), p. 21.

8. Southern, p. 21.

9. Southern, p. 23.

10. Southern, p. 24.

11. Southern, p. 25.

12. I wish to record here my gratitude to Giacomo Nerozzi of the Biblioteca dell'Archiginnasio for offering me a guided tour of the Teatro Anatomico in April 2008.

13. Giovanna Ferrari, "Public Anatomy Lessons and the Carnival: The Anatomy Theatre at Bologna," Past and Present 117 (1987), pp. 81-82. The quotation within Ferrari's quotation is from the Bologna State Archives.

14. Ferrari, p. 82.

15. Ferrari, p. 94.

16. Sawday, p. 73.

17. Heckscher, p. 98.

18. Reproduced in Heckscher, Pl. XXXIII-40, in Sawday, figure 6, and in Neill, p. 103.

19. A notable instance of this last category is Francis Barker's The Tremulous Private Body: Essays on Subjection (London: Methuen, 1984) in which Rembrandt's painting is reproduced as a frontispiece and discussed at some length (pp. 73-85).

20. Heckscher, p. 22.

21. For the identities of the persons in the portrait, I use the information given in Heckscher's Appendix III, pp. 188-92.

22. See, for example, The Riverside Shakespeare, ed. G. Blakemore Evans et al. (Boston: Houghton Mifflin, 1974), plate 8 following p. 494.

23. See Gerald Eades Bentley, The Jacobean and Caroline Stage, 7 vols. (Oxford: Clarendon Press, 1941-68), vol. 4, pp. 643, 666, 673.

24. Christian Billing, "Modelling the Anatomy Theatre and the Indoor Hall Theatre: Dissection on the Stages of Early Modern London," Early Modern Literary Studies 13 (2004), pp. 7-8.

25. See, for example, Heckscher, plate XVI-20.

26. See, for example, Carlino, pp. 42-53.

27. Sawday, p. 70. 
28. See Heckscher, p. 32.

29. Heckscher, p. 73.

30. Ferrari, pp. 66-68.

31. The Works of Sir Thomas Browne, ed. Geoffrey Keynes, $2^{\text {nd }}$ ed., 4 vols. (London: Faber, 1964), vol. 1, pp. 24-25.

32. See, for example, Edwin Wilson, The Theater Experience, $7^{\text {th }}$ ed. (New York: McGraw-Hill, 1998), p. 265. 